\title{
RELATIONSHIP BETWEEN EDAPHIC FACTORS AND VEGETATION IN SAVANNAS OF THE BRAZILIAN MIDWEST REGION
}

\author{
Michellia Pereira Soares(1)*, Paula Reys(2), Daniel Salgado Pifano(3), Janaílson Leônidas de \\ Sá(2), Patrícia Oliveira da Silva(2), Thailliny Moraes Santos(2) and Fabiano Guimarães Silva(2) \\ (1) Instituto Federal do Norte de Minas Gerais, Campus Salinas, Salinas, Minas Gerais, Brasil. \\ (2) Instituto Federal Goiano, Campus de Rio Verde, Rio Verde, Goiás, Brasil. \\ (3) Universidade Federal do Vale do São Francisco, Departamento de Ciências Biológicas, Petrolina, Pernambuco, Brasil. \\ * Corresponding author. \\ E-mail: michelliabot@gmail.com
}

\begin{abstract}
The Brazilian savanna is a mosaic of phytophysiognomies influenced by edaphic and topographic factors that range from the occurrence of fires to anthropic disturbance. The goal of this study was a comparative analysis between two cerrado areas in southeastern Goiás, relating the floristic composition and structure of the vegetation to soil properties to better understand the physiognomic characteristics of the region. Twenty-five $20 \times 20 \mathrm{~m}$ plots were used. All plants with circumference at breast height of more than $15 \mathrm{~cm}$ were measured. Soil samples collected at a depth of $0-20 \mathrm{~cm}$ were subjected to physical and chemical analyses. Canonical correspondence analysis (CCA) was used to detect possible correlations between the soil properties and species abundance and distribution. The density and total basal area were 1,647 ind/ha and $15.57 \mathrm{~m}^{2} / \mathrm{ha}$, respectively, in Ouroana. At this site, 107 species were sampled. In Montes Claros de Goiás, the density and total basal area were 781 ind/ha and $17.62 \mathrm{~m}^{2} / \mathrm{ha}$, and 120 species were sampled. The soil texture of Ouroana was sandy and significantly different from the medium to clayey texture of Montes Claros. The soils of both areas are dystrophic, however, more fertile in Montes Claros and aluminum-toxic in Ouroana. The species of vegetation were distributed according to soil fertility levels. The CCAs grouped species according to soil properties that defined location and abundance as well as the phytophysiognomies of the studied areas.
\end{abstract}

Keywords: canonical correspondence analysis, soil, cerrado. 


\title{
RESUMO: RELAÇÃO ENTRE FATORES EDÁFICOS E VEGETAÇÃO EM SAVANAS NO CENTRO-OESTE BRASILEIRO
}

\begin{abstract}
A savana brasileira forma um mosaico de fitofisionomias que está relacionado a fatores edáficos e topográficos, ocorrência de fogo e perturbações antrópicas. O objetivo deste trabalho foi fazer uma análise comparativa entre duas áreas de cerrado localizadas no sudoeste goiano (Ouroana e Montes Claros de Goiás), relacionando a estrutura e composição florística da vegetação às características edáficas. Foram utilizadas 25 parcelas de $20 \times 20 \mathrm{~m}$. Todos os indivíduos com CAP $\geq 15 \mathrm{~cm}$ foram mensurados. Para o estudo do solo, foram realizadas análises físicas e químicas com amostras coletadas de 0-20 cm de profundidade. Para verificar as possíveis correlações entre as características edáficas e a abundância e distribuição das espécies, foi utilizada a Análise de Correspondência Canônica (CCA). Ouroana apresentou densidade de 1.647 ind / ha e área basal total de 15,57 $\mathrm{m}^{2} / \mathrm{ha}$. Nesse ambiente, foram amostradas 107 espécies. Montes Claros de Goiás apresentou densidade de 781 ind/ha e área basal total de 17,62 m²/ha e 120 espécies amostradas. Os solos de Ouroana e Montes Claros de Goiás se apresentaram significativamente diferentes quanto à textura, sendo o de Ouroana arenoso e o de Montes Claros variando entre as texturas média e argilosa. As duas áreas possuem solos distróficos; porém, o de Montes Claros é mais fértil e o de Ouroana caracteriza-se por ser aluminotóxico. As espécies estão distribuídas de acordo com os níveis de fertilidade do solo. A CCA agrupou espécies de acordo com as características edáficas que definiram a localização e a abundância das espécies, bem como as fitofisionomias das áreas estudadas.
\end{abstract}

Palavras-chave: análise de correspondência canônica, solo, cerrado.

\section{INTRODUCTION}

The Brazilian savanna is a mosaic of phytophysiognomies under the influence of soil and topographic factors, ranging from the occurrence of fires to anthropic disturbances (Oliveira-Filho et al., 1990). The main edaphic factors that determine this physiognomic diversity are soil and water table depths, drainage, the presence of concretions in the soil profile, and fertility (Haridasan, 1992).

The predominant physiognomies in the core area of the cerrado domain, where the State of Goiás is located, are the 'cerrado típico', 'cerrado rupestre' (open wooded savannah with rocky outcrops) and 'cerradão' (savanna forest). According to Ribeiro and Walter (2008), the 'cerrado sensu stricto' is subdivided into four types based on density or the environment in which they are found, namely: 'cerrado denso' (savanna with a dense tree cover), 'cerrado típico' (typical cerrado), 'cerrado ralo' (savanna with a sparse tree cover) and 'cerrador rupestre'. The 'cerrado típico' usually occurs on Latosols and quartz-sand soils, which are deep, well-drained, acidic and alic, and only rarely in mesotrophic soils (Haridasan, 1992). 'Cerradão', in turn, can be found in dystrophic and mesotrophic soils, with floristic composition varying according to the soil fertility (Marimon Junior and Haridasan, 2005).

Many authors noted that the availability of nutrients in the soil is one of the most important factors in determining the phytophysiognomic diversity of the cerrado. A study conducted by Goodland and Pollard (1973) in Minas Gerais found a positive correlation between the cerrado physiognomic gradient and edaphic variables related to the levels of $\mathrm{N}, \mathrm{P}$ and $\mathrm{K}$, which contradicts the results of other authors who found no such correlation (Haridasan, 1992). Arens (1963) reported that the amounts of exchangeable $\mathrm{Al}$ might be related to the structure and composition of the vegetation, consistent with the results of Goodland and Pollard (1973), who showed the basal area of trees to be negatively correlated with exchangeable Al. By contrast, a comparative study by Haridasan (1992) between the cerrado regions of the Federal District and Goiás found no evidence of a link between the occurrence of cerrado and the $\mathrm{Al}$ concentration of the soil solution. Thus, the results remain conflicting and inconclusive, requiring new studies that compare different cerrado areas in terms of structure, diversity and edaphic variables.

Considerable knowledge has been obtained for cerrado vegetation in studies related to the floristic composition and phytosociology, especially those developed in the central cerrado areas, namely, the central region of Goiás, which includes the Federal District (Felfili and Fagg, 2007). However, other regions of the State, e.g., southeastern Goiás, are lagging behind in information concerning the distribution, abundance and structure of cerrado species in relation to soil properties. The goal of this study was therefore a comparative analysis between two cerrado areas in southeastern Goiás, relating the floristic composition and structure of the vegetation to soil properties to better understand the physiognomic characteristics of the region. 


\section{MATERIAL AND METHODS}

\section{Characterization of the study areas}

This study was conducted in southeastern Goiás, namely, in the district of Ouroana in the municipality of Rio Verde (18 $06^{\circ} 12^{\prime \prime}-18^{\circ} 05^{\prime} 57^{\prime \prime} \mathrm{S}$, $\left.50^{\circ} 38^{\prime} 37^{\prime \prime}-50^{\circ} 39^{\prime} 32^{\prime \prime} \mathrm{W}\right)$, in the Preto River basin, at an approximate elevation of $721 \mathrm{~m}$, and also in the municipality of Montes Claros de Goiás (16 08' 18” - $\left.16^{\circ} 06^{\prime} 24^{\prime \prime} \mathrm{S}, 51^{\circ} 18^{\prime} 24^{\prime \prime}-51^{\circ} 15^{\prime} 37^{\prime \prime} \mathrm{W}\right)$, in the Claro River microbasin, at an elevation of approximately $392 \mathrm{~m}$.

According to the Köppen classification, the climate of these locations is Aw, which is a tropical and humid climate type, with dry winters from April to September and maximal summer rains from October to March. In the district of Ouroana, approximately $80 \%$ of the annual pluvial precipitation (between 1,200 and $1,700 \mathrm{~mm}$ ) occurs during the rainy season, with monthly values of more than $120 \mathrm{~mm}$. The highest monthly average temperatures are approximately $20^{\circ} \mathrm{C}$, and the annual temperature range is less than $6^{\circ} \mathrm{C}$. In the municipality of Montes Claros de Goiás, the pluvial precipitation is more regularly distributed, varies annually between 1,000 and $1,700 \mathrm{~mm}$ and occurs during the rainy season, with monthly values exceeding $140 \mathrm{~mm}$. The highest monthly average temperatures are approximately $19{ }^{\circ} \mathrm{C}$, and the annual temperature range is less than $7{ }^{\circ} \mathrm{C}$ (Seplan-GO, 2005).

Both study areas are within the phytogeographic domain of cerrado, and the predominant phytophysiognomies are 'cerradão' and 'cerrado sensu stricto' (Ribeiro and Walter, 2008). These physiognomies occur in exclusively rural locations: the study area in Ouroana is surrounded by extensive plantations of soybean, corn and sugar cane, whereas the study area in Montes Claros by pastures used for dairy cattle farming, some of which have been abandoned. In both study areas, Latossolo Vermelho (Oxisol) is predominant.

\section{Vegetation sampling}

Twenty-five $20 \times 20 \mathrm{~m}$ plots were randomly established in each area, with a total of 1-ha of sample area. All plants with a circumference at breast height $(\mathrm{CBH}$ at approximately $1.30 \mathrm{~m}$ above the soil) $\geq 15 \mathrm{~cm}$, including dead but still standing plants, were measured and their heights estimated. The species were classified according to the system of the Angiosperm Phylogeny Group III (Bremer et al., 2009). All collected fertile material was prepared and deposited in the Rio Verde Herbarium (IFRV) of the Federal Institute Goiano on the Rio Verde Campus.

To describe the tree and shrub community structure of the study areas, phytosociological parameters were calculated as proposed by Mueller-Dombois and Ellenberg (1974), along with Shannon's diversity (H') and Pielou's evenness (J') indices (Magurran, 2004).

\section{Soil sampling and analysis}

The soil was collected in November 2011, to blend one composite sample of five random samples per plot. The slope of all plots was the same.

The soil was sampled at a random point of each plot at a depth of $0-20 \mathrm{~cm}$, with an auger. The chemical and physical analyses were conducted in the Soil Analysis Laboratory of the Federal University of Lavras, in the State of Minas Gerais according to the protocol of Embrapa (1997). The chemical analyses measured the following variables: soil $\mathrm{pH}\left(\mathrm{H}_{2} \mathrm{O}\right) ; \mathrm{P}, \mathrm{Na}, \mathrm{K}, \mathrm{Zn}, \mathrm{Mn}$ and $\mathrm{Cu}$ by the Mehlich- 1 extraction method; $\mathrm{Ca}, \mathrm{Mg}$ and $\mathrm{Al}$ by extraction with $1 \mathrm{~mol} / \mathrm{L} \mathrm{KCl} ; \mathrm{H}+\mathrm{Al}$ by extraction of soluble microbial products (SMP); $\mathrm{B}$ by hot water extraction; S using extraction by monocalcium phosphate in acetic acid; sum of exchangeable bases (SB); effective cation exchange capacity [CEC(t)]; cationic exchange capacity at $\mathrm{pH} 7.0[\mathrm{CEC}(\mathrm{T})]$; base saturation index (V); Al saturation index (m); organic matter (OM) after oxidation with $0.5 \mathrm{~mol} / \mathrm{L} \mathrm{Na}_{2} \mathrm{Cr}_{2} \mathrm{O}_{7}$, and $5 \mathrm{~mol} / \mathrm{L} \mathrm{H}_{2} \mathrm{SO}_{4}$; and remaining $\mathrm{P}$ (P-rem), using $0.01 \mathrm{~mol} / \mathrm{L} \mathrm{CaCl}_{2}$. The physical analysis determined the percentages of sand, silt and clay, and the soils were classified in sandy, medium or clayey texture.

The nonparametric Mann-Whitney test (U), which compares two independent samples, was used to analyze the differences in chemistry and texture between the soils of Ouroana and Montes Claros.

\section{Soil and vegetation data ordination}

Canonical correspondence analysis (Ter Braak, 1987) was used to detect correlations between the abundance and distribution of species and the edaphic factors. Two matrices were assembled using software PC-ORD (McCune and Mefford, 1997): the main matrix contained absolute density (AD) data on species for which at least 15 plants were found - 34 species in Ouroana and 13 in Montes Claros - and the secondary matrix contained non-collinear edaphic variables. These edaphic variables were sand, clay, $\mathrm{Mg}, \mathrm{K}$, $\mathrm{Ca}, \mathrm{pH}\left(\mathrm{H}_{2} \mathrm{O}\right), \mathrm{Cu}, \mathrm{H}+\mathrm{Al}, \mathrm{Zn}$, and $\mathrm{Al}$ for Montes Claros and sand, clay, $\mathrm{Mn}, \mathrm{Cu}, \mathrm{Al}, \mathrm{pH}\left(\mathrm{H}_{2} \mathrm{O}\right), \mathrm{Zn}$, and $\mathrm{H}+\mathrm{Al}$ for Ouroana. The significance level of the canonical ordination axes was analyzed by the Monte Carlo test, which can be applied to determine the reliability of correlations found between soil variables and plant species (Ter Braak and Prentice, 1988). 


\section{RESULTS}

\section{Floristic composition}

In Ouroana, 1,647 trees from over 42 families, 78 genera and 107 species were sampled. The families represented by the most species were Fabaceae (17), Vochysiaceae (8), Annonaceae (6) Malpighiaceae (6) and Malvaceae (5), whereas the genera with the greatest representation were Byrsonima with six species, Erythroxylum, Kielmeyera and Tabebuia with four each and Aspidosperma and Qualea with three each. In Montes Claros, the total number of plants sampled was 781; the plants were distributed among 40 families, 91 genera and 120 species. Species richness and diversity were greater in Montes Claros but evenness was the same as in Ouroana (Table 1). The best-represented families in terms of species were Fabaceae (21); Malvaceae (8); Apocynaceae, Malpighiaceae, Rubiaceae and Vochysiaceae, with six each; and Anacardiaceae and Myrtaceae, with five each. The genera with the most species were Byrsonima (6), Aspidosperma (5), Qualea (4) and Guapira, Kielmeyera and Luehea (3). Rare species, i.e., those for which a single plant was found in the sample, contributed with 33 plants or $27.5 \%$ of the total floristic richness. Among these rare are some typical cerrado species, such as Myrsine guianensis, Couepia grandiflora, Guettarda macrantha and Dimorphandra mollis.

The two study areas had 52 species in common, with 19 exclusive to Ouroana and 40 exclusive to Montes Claros de Goiás (Table 1). In both studied areas the richness, diversity and evenness were high, despite a larger number of exclusive species and a greater total basal area in Montes Claros de Goiás.

\section{Structure}

The best-represented species and categories in Ouroana were Qualea multiflora (16.12), Guapira opposita (14.07), dead plants (12.44), Buchenavia tomentosa (12.36), Hyptidendron canum (10.50), and Emmotum nitens (9.55). Qualea multiflora and G. opposita had the highest density and dominance (7.56 ind/ha and $5.71 \mathrm{~m}^{2} / \mathrm{ha}$ and $4.36 \mathrm{ind} / \mathrm{ha}$ and $6.56 \mathrm{~m}^{2} / \mathrm{ha}$, respectively), followed by the category of dead trees, which also showed relatively high dominance and density values $\left(5.02 \mathrm{~m}^{2} / \mathrm{ha}\right.$ and $4.13 \mathrm{ind} / \mathrm{ha}$ ), with $90 \%$ of the allocated plots having dead but standing trees (almost three dead trees per plot). Hyptidendron canum had high density and relative frequency values (4.49 ind/ha and 2.29 , respectively), similarly to $E$. nitens (3.28 ind/ha and 2.15 ) and $B$. tomentosa (3.64 ind/ha and 3.15).

The best-represented species in the community of Montes Claros de Goiás were the following: Myracrodruon urundeuva (4.65), Curatella americana (4.65), Magonia pubescens (4.44), Xylopia sericea (4.17), and Hymenaea stigonocarpa (3.26).
Table 1. Structural descriptors of vegetation and diversity of species sampled in cerrado fragments in southeastern Goiás, Brazil

\begin{tabular}{lcc}
\hline Descriptor & $\begin{array}{c}\text { Montes Claros } \\
\text { de Goiás }\end{array}$ & Ouroana \\
\hline Number of plots & 25 & 25 \\
Number of families & 40 & 42 \\
Number of species & 120 & 107 \\
Number of exclusive species & 40 & 19 \\
Total density (ind/ha) & 781 & 1,647 \\
Total basal area (m²/ha) & 17.62 & 15.57 \\
Diversity index (H') & 4.15 & 4.05 \\
Evenness index (J') & 0.86 & 0.86 \\
\hline
\end{tabular}

For $M$. urundeuva, the relative dominance value was high $\left(7.51 \mathrm{~m}^{2} / \mathrm{ha}\right)$, as for C. americana $\left(5.11 \mathrm{~m}^{2} / \mathrm{ha}\right)$ and $M$. pubescens $\left(5.08 \mathrm{~m}^{2} / \mathrm{ha}\right)$. Xylopia sericea and $H$. stigonocarpa had high relative dominance as well as high density values $\left(2.73 \mathrm{~m}^{2} / \mathrm{ha}\right.$ and $7.55 \mathrm{ind} / \mathrm{ha}$ and $2.71 \mathrm{~m}^{2} / \mathrm{ha}$ and $3.84 \mathrm{ind} / \mathrm{ha}$, respectively).

\section{Soil characterization}

In both areas, soil acidity was moderate, $\mathrm{P}$ contents very low, OM contents average. and base saturation (V) below $50 \%$, and were therefore characterized as dystrophic (Lopes and Guilherme, 1992) (Table 2). In addition, the area of Montes Claros presented an average content of potassium considered unsuitable for agricultural areas, unlike that found for Ouroana (Table 2). However, in spite of the similarities, the clay content in soil of Montes Claros was significantly higher than in Ouroana $(\mathrm{U}=109 ; \mathrm{p}=0.00)$, and chemically, the soils of the studied areas differed significantly in terms of fertility ( $U=156 ; p=0.00)$, which was higher in Montes Claros, and in terms of $\mathrm{Al}$ saturation ( $\mathrm{U}=134 ; \mathrm{p}=0.00)$, which was higher and indicated soil Al toxicity in Ouroana.

The soil of Ouroana differed significantly in texture from that of Montes Claros $(U=97 ; p=0.00)$. The Ouroana study area was characterized by the predominance of sandy soil in $60 \%$ (15) of the plots, whereas a medium soil texture was observed in eight plots, and clayey soil was found in only two. Mostly, the soil of the Montes Claros de Goiás study area had a medium (4\%) or clayey (32\%) texture, and only five plots with sandy soil were found (Table 2).

\section{Correlation between edaphic factors and vegetation}

In the cerrado of Ouroana, the eigenvalues for the two first axes were low $(0.27$ and 0.13 , respectively), explaining 15.1 and $22.7 \%$, respectively, of the total cumulative variance. Moreover, the relationship between species and soil properties was not significant, as the CCA 
Table 2. Chemical and physical soil properties of the superficial soil layer $(0-20 \mathrm{~cm}$ depth) sampled from cerrado fragments in southeastern Goiás, Brazil

\begin{tabular}{|c|c|c|}
\hline Attribute & Montes Claros & Ouroana \\
\hline $\mathrm{pH}\left(\mathrm{H}_{2} \mathrm{O}\right)$ & $5.44 \pm 0.41 \mathrm{a}$ & $5.16 \pm 0.21(b)$ \\
\hline $\mathrm{P}\left(\mathrm{mg} / \mathrm{dm}^{3}\right)$ & $3.28 \pm 4.4$ & $2.48 \pm 0.1$ \\
\hline $\mathrm{K}\left(\mathrm{mg} / \mathrm{dm}^{3}\right)$ & $105.16 \pm 73.49$ (a) & $65.76 \pm 2.63(\mathrm{~b})$ \\
\hline $\mathrm{Ca}^{2+}\left(\mathrm{cmol}_{\mathrm{c}} / \mathrm{dm}^{3}\right)$ & $3.00 \pm 4.71$ (a) & $0.49 \pm 0.02(\mathrm{~b})$ \\
\hline $\mathrm{Mg}^{2+}\left(\mathrm{cmol}_{\mathrm{c}} / \mathrm{dm}^{3}\right)$ & $0.99 \pm 0.9$ & $0.60 \pm 0.02$ \\
\hline $\mathrm{Al}^{3+}\left(\mathrm{cmol}_{\mathrm{c}} / \mathrm{dm}^{3}\right)$ & $0.42 \pm 0.35$ (a) & $0.77 \pm 0.03(\mathrm{~b})$ \\
\hline $\mathrm{H}+\mathrm{Al}\left(\mathrm{cmol}_{\mathrm{c}} / \mathrm{dm}^{3}\right)$ & $4.54 \pm 1.23$ & $4.32 \pm 0.17$ \\
\hline $\mathrm{SB}\left(\mathrm{cmol}_{\mathrm{c}} / \mathrm{dm}^{3}\right)$ & $4.26 \pm 5.42$ (a) & $1.36 \pm 0.05(\mathrm{~b})$ \\
\hline $\mathrm{t}\left(\mathrm{cmol}_{\mathrm{c}} / \mathrm{dm}^{3}\right)$ & $4.68 \pm 5.2(\mathrm{a})$ & $2.14 \pm 0.09$ (b) \\
\hline $\mathrm{T}\left(\mathrm{cmol}_{\mathrm{c}} / \mathrm{dm}^{3}\right)$ & $8.83 \pm 4.7$ (a) & $5.71 \pm 0.23(\mathrm{~b})$ \\
\hline V (\%) & $22.89 \pm 12.75$ & $23.19 \pm 0.93$ \\
\hline m (\%) & $20.70 \pm 20(a)$ & $40.63 \pm 1.63(\mathrm{~b})$ \\
\hline $\mathrm{OM}$ (dag/kg) & $3.63 \pm 1.59$ (a) & $2.36 \pm 0.09(\mathrm{~b})$ \\
\hline P-rem (mg/L) & $19.31 \pm 8.14(\mathrm{a})$ & $28.58 \pm 1.14(\mathrm{~b})$ \\
\hline $\mathrm{Zn}\left(\mathrm{mg} / \mathrm{dm}^{3}\right)$ & $0.78 \pm 0.64$ (a) & $2.78 \pm 0.11(\mathrm{~b})$ \\
\hline $\mathrm{Fe}\left(\mathrm{mg} / \mathrm{dm}^{3}\right)$ & $89.39 \pm 86.59$ & $73.46 \pm 2.94$ \\
\hline $\operatorname{Mn}\left(\mathrm{mg} / \mathrm{dm}^{3}\right)$ & $54.60 \pm 31.21(\mathrm{a})$ & $22.32 \pm 0.89(\mathrm{~b})$ \\
\hline $\mathrm{Cu}\left(\mathrm{mg} / \mathrm{dm}^{3}\right)$ & $2.15 \pm 0.87$ (a) & $1.36 \pm 0.05(\mathrm{~b})$ \\
\hline $\mathrm{B}\left(\mathrm{mg} / \mathrm{dm}^{3}\right)$ & $0.13 \pm 0.06$ (a) & $0.09 \pm 0.00(\mathrm{~b})$ \\
\hline $\mathrm{S}\left(\mathrm{mg} / \mathrm{dm}^{3}\right)$ & $9.21 \pm 3.12$ (a) & $6.57 \pm 0.26(\mathrm{~b})$ \\
\hline Sand (dag/kg) & $53.6 \pm 22.43(\mathrm{a})$ & $77.08 \pm 15.88(b)$ \\
\hline Silt (dag/kg) & $14.52 \pm 6.42(\mathrm{a})$ & $7.36 \pm 6.58(\mathrm{~b})$ \\
\hline Clay (dag/kg) & $31.88 \pm 17.5$ (a) & $15.56 \pm 9.68(\mathrm{~b})$ \\
\hline
\end{tabular}

SB: sum of exchangeable bases, t: effective cation exchange capacity, T: cation exchange capacity at pH 7.0, V: base saturation index and $\mathrm{m}$ : $\mathrm{Al}$ saturation index. Within characteristics, the letters a and $b$ indicate significant differences between locations (Mann-Whitney $\mathrm{U}$ test, $\mathrm{p}<0.05$ ). yielded low correlations for the first two axes (0.82 and 0.77, respectively), and the Monte Carlo permutation test indicated that the abundance of species and the soil physical and chemical variables were not significantly correlated.

For Montes Claros, the CCA eigenvalues for the first two axes were relatively high (0.68 and 0.38 , respectively). The correlations between the axes of the species and those of the soil properties were significant, with values of 0.93 for the first axis and 0.95 for the second.

In Ouroana, there was a stronger relation between the edaphic variables and the second axis, in particular, when the following variables, listed in decreasing order of strength, were involved: $\mathrm{V}, \mathrm{Mn}$, $\mathrm{Al}$ or $\mathrm{H}+\mathrm{Al}$ (Table 3). In Montes Claros, the edaphic variables correlated more strongly with the first axis, in particular, when $\mathrm{Zn}, \mathrm{pH}\left(\mathrm{H}_{2} \mathrm{O}\right)$ or $\mathrm{Ca}$ were the variables involved (Table 4 ). The weighted correlations also showed strong intercorrelation between the nine variables assessed in Ouroana (Table 3) and the 10 variables from Montes Claros (Table 4). In Ouroana, the following correlations were particularly noteworthy: sand, clay and $\mathrm{Cu}$; $\mathrm{Al}$ with $\mathrm{H}+\mathrm{Al}, \mathrm{V}, \mathrm{Zn}$, or $\mathrm{Mn}$; and $\mathrm{H}+\mathrm{Al}$ with $\mathrm{V}, \mathrm{Zn}$ or Mn (Table 3). In Montes Claros, strong intercorrelation occurred for $\mathrm{pH}\left(\mathrm{H}_{2} \mathrm{O}\right)$ with $\mathrm{K}$, Ca, $\mathrm{Mg}, \mathrm{Al}$, and $\mathrm{H}+\mathrm{Al}$; for $\mathrm{Ca}$ with $\mathrm{Al}$ and $\mathrm{H}+\mathrm{Al}$; and for $\mathrm{Mg}$ with $\mathrm{Al}$ and $\mathrm{Zn}$ (Table 4).

The CCA ordination of the species data for Ouroana suggested that $Q$. multiflora, the dead category, G. opposita, Dalbergia miscolobium, Rudgea viburnoides, M. urundeuva, Qualea parviflora, Ouratea castaneifolia, Vatairea macrocarpa, Guapira noxia, $H$. canum, Terminalia argentea, Diospyros burchellii, Roupala montana, and Aspidosperma tomentosum tend to be more

Table 3. Canonical correspondence analysis (CCA) of the abundance of 34 species sampled in 25 plots located in Ouroana, municipality of Rio Verde, Goiás, Brazil

\begin{tabular}{|c|c|c|c|c|c|c|c|c|c|c|}
\hline \multirow{2}{*}{ Edaphic variable } & \multicolumn{2}{|c|}{ Weighted correlation } & \multirow[b]{2}{*}{ Sand } & \multirow[b]{2}{*}{ Clay } & \multirow[b]{2}{*}{$\mathrm{pH}\left(\mathrm{H}_{2} \mathrm{O}\right)$} & \multirow[b]{2}{*}{$\mathrm{Al}^{3+}$} & \multirow[b]{2}{*}{$\mathrm{H}+\mathrm{Al}$} & \multirow[b]{2}{*}{ V } & \multirow[b]{2}{*}{ Zn } & \multirow[b]{2}{*}{ Mn } \\
\hline & Axis 1 & Axis 2 & & & & & & & & \\
\hline Sand & 0.888 & 0.144 & & & & & & & & \\
\hline Clay & -0.916 & -0.026 & -0.975 & & & & & & & \\
\hline $\mathrm{pH}\left(\mathrm{H}_{2} \mathrm{O}\right)$ & -0.348 & -0.254 & -0.292 & 0.253 & & & & & & \\
\hline $\mathrm{Al}^{3+}$ & 0.331 & -0.583 & 0.241 & -0.132 & -0.198 & & & & & \\
\hline $\mathrm{H}+\mathrm{Al}$ & -0.277 & -0.567 & -0.254 & 0.382 & 0.045 & 0.691 & & & & \\
\hline $\mathrm{V}$ & -0.182 & 0.617 & -0.105 & -0.005 & 0.009 & -0.803 & -0.773 & & & \\
\hline $\mathrm{Zn}$ & 0.133 & 0.381 & 0.083 & -0.164 & -0.090 & -0.528 & -0.656 & 0.774 & & \\
\hline $\mathrm{Mn}$ & -0.196 & 0.585 & -0.074 & 0.010 & -0.077 & -0.663 & -0.656 & 0.803 & 0.661 & \\
\hline $\mathrm{Cu}$ & -0.378 & 0.331 & -0.605 & 0.606 & -0.088 & 0.051 & 0.264 & -0.103 & -0.095 & 0.053 \\
\hline
\end{tabular}

Internal correlations between edaphic variables and the first two ordination axes; and weighted correlations between the edaphic variables used in this analysis. Correlations for which the absolute value exceeds 0.5 are highlighted in boldface. 
abundant in sandy soils with high Mn content (Figure 1). Coccoloba brasiliensis and X. sericea had higher densities in sandy soils, and Qualea grandiflora, Tapirira guianensis, E. nitens, Vochysia tucanorum, and Virola sebifera were more commonly found in Al-rich soils (Figure 1). B. tomentosa, Talisia esculenta, Acosmium dasycarpum, Erythroxylum suberosum, Handroanthus ochraceus, Neea theifera, and Psidium cattleyanum were associated with clayey soils and high $\mathrm{H}+\mathrm{Al}$ contents, while Styrax camporum, Annona coriacea, Eriotheca pubescens, and $C$. americana were more abundant in acidic soils with high Zn content (Figure 1).

In Montes Claros, the CCA identified two groups of species. The first group was associated with a high $\mathrm{Al}$ content of the soil and consisted of C. americana, V. macrocarpa, A. dasycarpum, A. tomentosum, $X$. sericea, $A$. coriacea, and $H$. stigonocarpa. The second group tended to occur in clayey soils with a high $\mathrm{H}+\mathrm{Al}$ content and consisted of Luehea divaricata, Byrsonima verbascifolia, Q. grandiflora, M. urundeuva, and M. pubescens (Figure 2).

In Ouroana, the CCA basically divided the plots into four groups, represented by the four quadrants in the Cartesian plane. Group 1 contains plots 1 , $2,3,5,6$, and 8 , located in 'cerrado rupestre' and strongly associated with soil $\mathrm{Zn}$ content, and plots 17, 18 and 21, associated with acidic soils; group 2 contains plots $12,13,15,16$, and 22 , associated with sandy soils rich in $\mathrm{Cu}$ and covered by 'cerradão' vegetation; group 3 comprised plots 11, 19, 23, 24 , and 25 , associated with high Mn content and also covered by 'cerradão' vegetation, similarly to group 2; and group 4 comprised plots 4, 7, 9, 10, and 20 , which were more strongly association with more fertile soils, rich in clay and organic matter. In Montes Claros, most of the plots were assigned to two groups, both covered by 'cerradão' vegetation. The first group was associated with sandy soils and high soil $\mathrm{Al}$ contents (plots 1, 2, 3, 4, 6, 8, 9, 11 , and 14), and the second group with high OM percentage (plots $5,7,10,13,15,16,17,18,19,21$, and 22). Another two groups associated with $\mathrm{Zn}$ and Mn contents and with clay and fertility contained three and two plots, respectively (plots 12, 24 and 25 and plots 20 and 23). Note that plots 20 and 23 do not correspond to any of the species represented by least 15 plants.

\section{DISCUSSION}

Of the most abundant species in Ouroana, $Q$. multiflora and E. nitens are typical of 'cerrado sensu stricto' (Ribeiro and Walter, 2008), G. opposita can occur both in 'cerradão' and semideciduous seasonal forest (Pereira-Silva et al., 2004), and H. canum was recorded in a study area with physiognomies of 'cerrado sensu stricto', 'campos rupestres' (montane savanna) and riparian forest (Costa et al., 2010). B. tomentosa and T. esculenta are found in the transition between dystrophic 'cerradão' and dry and/or riparian forests of the Brazilian Midwest (Soares et al., 2012), and P. cattleyanum is notably common in restinga (sandbank) woods (Scherer et al., 2005). The remaining species are among the 914 recorded by Ratter et al. (2003) in the core area of the Brazilian cerrado. There is no apparent dominance in the vegetation of Ouroana, although the richness can be considered high when compared with other studies within the domain (Ratter et al., 2001). The same holds for the diversity, which is among the highest found in the 170 areas studied by Ratter et al. (2001). It may therefore be inferred that there is an ecotonal vegetation strip in Ouroana that is positioned in terms of its soil properties, floristic composition and

Table 4. Canonical correspondence analysis (CCA) of the abundance of 13 species sampled in 25 plots located in the municipality of Montes Claros de Goiás, Goiás, Brazil

\begin{tabular}{|c|c|c|c|c|c|c|c|c|c|c|c|}
\hline \multirow{2}{*}{$\begin{array}{l}\text { Edaphic } \\
\text { variable }\end{array}$} & \multicolumn{11}{|c|}{ Weighted correlation } \\
\hline & Axis 1 & Axis 2 & Sand & Clay & $\mathrm{pH}\left(\mathrm{H}_{2} \mathrm{O}\right)$ & $\mathbf{K}$ & $\mathbf{C a}^{2+}$ & $\mathrm{Mg}^{2+}$ & $\mathrm{Al}^{3+}$ & $\mathrm{H}+\mathrm{Al}$ & $\mathrm{Zn}$ \\
\hline Sand & 0.210 & 0.884 & & & & & & & & & \\
\hline Clay & -0.184 & -0.893 & -0.982 & & & & & & & & \\
\hline $\mathrm{pH}\left(\mathrm{H}_{2} \mathrm{O}\right)$ & -0.589 & -0.306 & -0.376 & 0.291 & & & & & & & \\
\hline K & -0.479 & -0.073 & -0.114 & 0.110 & 0.611 & & & & & & \\
\hline $\mathrm{Ca}^{2+}$ & -0.515 & -0.182 & -0.142 & 0.060 & 0.800 & 0.246 & & & & & \\
\hline $\mathrm{Mg}^{2+}$ & -0.809 & 0.002 & -0.206 & 0.162 & 0.674 & 0.769 & 0.447 & & & & \\
\hline $\mathrm{Al}^{3+}$ & 0.439 & 0.051 & 0.282 & -0.176 & -0.765 & -0.466 & -0.588 & -0.631 & & & \\
\hline $\mathrm{H}+\mathrm{Al}$ & 0.468 & -0.307 & -0.216 & 0.333 & -0.609 & -0.321 & -0.593 & -0.448 & 0.644 & & \\
\hline $\mathrm{Zn}$ & -0.679 & 0.280 & 0.225 & -0.276 & 0.307 & 0.269 & 0.340 & 0.588 & -0.268 & -0.431 & \\
\hline $\mathrm{Cu}$ & -0.367 & -0.475 & -0.689 & 0.703 & 0.058 & 0.234 & -0.177 & 0.232 & 0.003 & 0.296 & -0.135 \\
\hline
\end{tabular}

Internal correlations between edaphic variables and the first two ordination axes; and weighted correlations between the edaphic variables used in this analysis. Correlations for which the absolute value exceeds 0.5 are highlighted in boldface. 
(a)

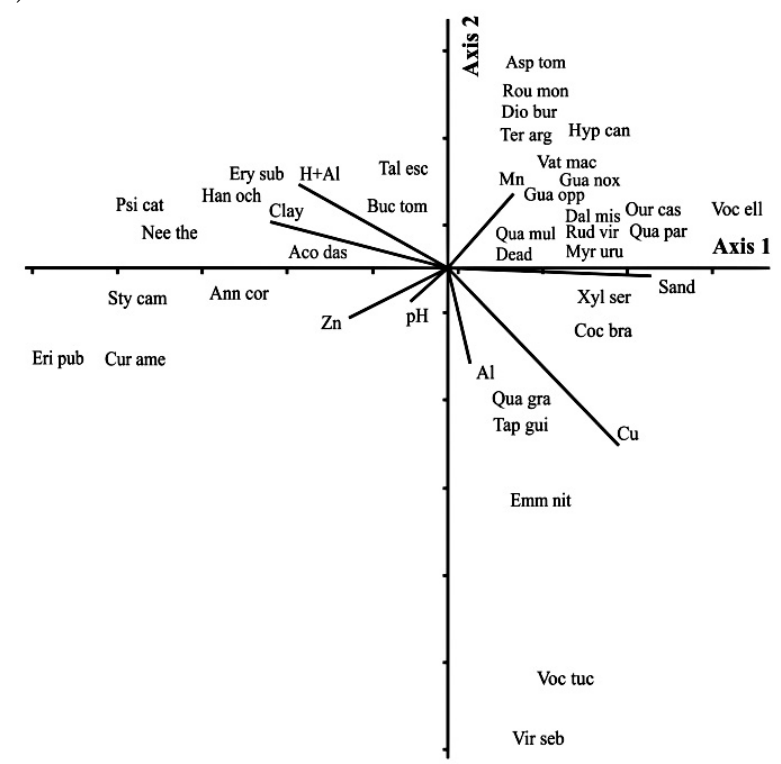

(b)

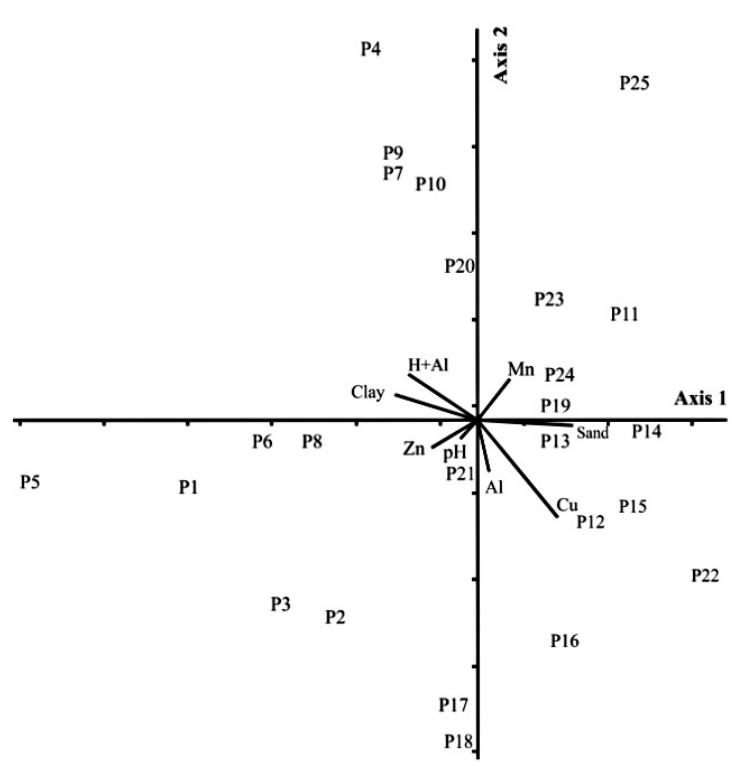

Figure 1. Ordination plots for species (a) and plots (b) resulting from canonical correspondence analysis based on the density distribution of 34 tree and shrub species represented by at least 15 or more plants in the cerrado of Ouroana, Goiás. Edaphic variables are represented by the following vectors: $\mathrm{H}+\mathrm{Al}$ : potential acidity, $\mathrm{Cu}$ : copper, Al: aluminum, $\mathrm{Zn}$ : zinc, $\mathrm{Mn}$ : manganese, clay, sand and pH: hydrogen ion concentration.

structure between the dystrophic 'cerradão' and the semideciduous and riparian forests. Despite the recurring anthropic disturbance of the study area, the results indicated the typical environmental heterogeneity of the cerrado domain. In this regard, the relevant results are the high evenness, richness and diversity indices, together with the (a)

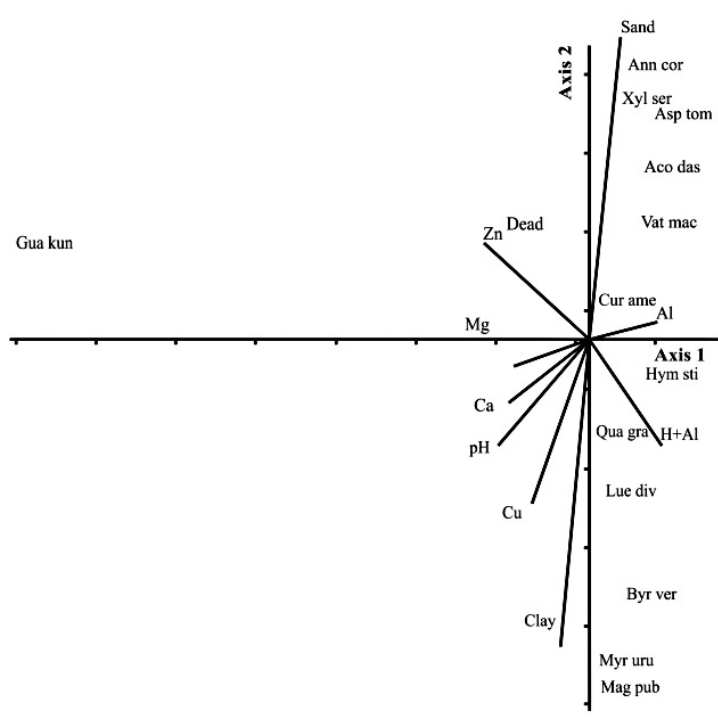

(b)

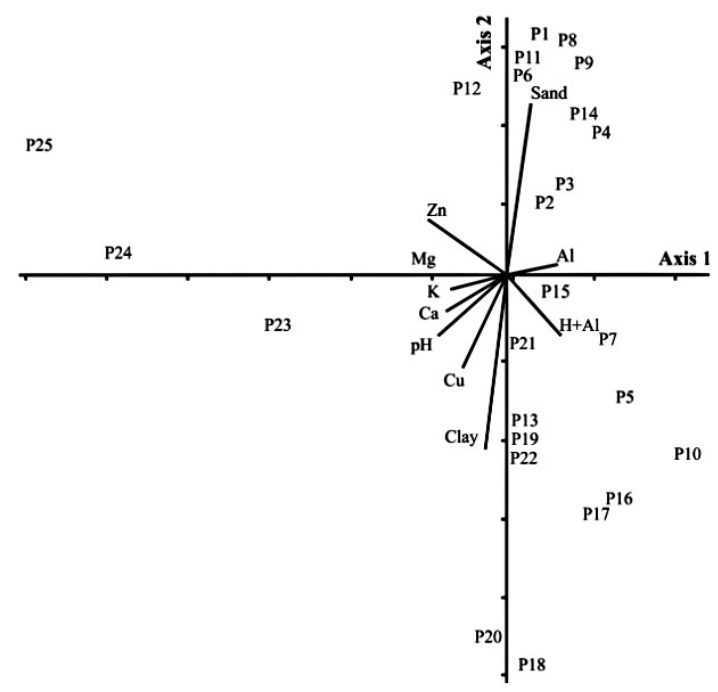

Figure 2. Ordination plots for species (a) and plots (b) resulting from canonical correspondence analysis based on the density distribution of 13 tree and shrub species represented by at least 15 or more plants in the cerrado of Montes Claros Goiás. Edaphic variables are represented by the following vectors: $\mathrm{H}+\mathrm{Al}$ : potential acidity, $\mathrm{Cu}$ : copper, $\mathrm{Al}$ : aluminum, $\mathrm{Zn}$ : zinc, Mg: magnesium, clay, sand, $\mathrm{pH}$ : hydrogen ion concentration, Ca: calcium, and K: potassium.

presence of species originally from other vegetation physiognomies, such as dry and riparian woods.

Montes Claros de Goiás is a complex vegetation mosaic consisting of 'veredas', 'cerradão', 'parque cerrado' and 'cerrado rupestre', with great richness and diversity. According to Ribeiro et al. (1985), the representation of the main families reflects the landscape richness of an area, as occurred in the Montes Claros area, in which the families 
Myrtaceae and Rubiaceae were relevant in the flora composition. The Fabaceae family was notable because of its great richness, both in Montes Claros and Ouroana as well as in most of the 170 cerrado areas surveyed by Ratter et al. (2001). This richness may indicate the strong adaptive radiation of this family, initiated in the Quaternary, the period of origin of the savannas of central Brazil (Klein, 1975).

The genera Byrsonima, Aspidosperma, Qualea and Kielmeyera were frequent in Montes Claros and are typical floristic components in 'cerrado sensu stricto' and 'cerradão' areas (Ratter et al., 2001).The genera Guapira and Luehea have a high richness and are well-represented in the entire Brazilian flora, especially the vegetation of the Atlantic and Amazonian forests (Oliveira-Filho and Fontes, 2000). In the vegetation of Montes Claros, the highest importance values were similar to one another and shared by a number of species; thus, there was no ecologically dominant species in this vegetation. $M$. pubescens, a tree widely distributed throughout the cerrado prefers deeper, well-drained soils (Ribeiro and Walter, 2008) and is an indicator of mesotrophic soils (Otoni et al., 2013), which is consistent with the results of this study, where this species was strongly associated with high clay and $\mathrm{OM}$ contents. According to Ratter et al. (2001), a mesotrophic 'cerradão' has less acidic soils, with more nutrients and OM, and $M$. pubescens is the best-represented species in this type of vegetation. Curatella americana is well distributed in the 'cerrado sensu lato'. This tree, which is light-demanding but considered to be quite generalist in soil requirements, is usually found in sandy soils (Ratter et al., 2001). These conditions were met in Montes Claros, where this species was correlated with sandy soils and high Al contents. $X$. sericea colonizes disturbed areas rather aggressively, and the high density at which it occurred indicated interventions in land use and occupation at many sites of Montes Claros, similarly to Ouroana.

As of $C$. americana and $M$. pubescens, the absolute dominance of $M$. urundeuva was also high; however, the low absolute density of the latter species was attributable to the characteristics of its wood. This wood is valued for the manufacture of furniture and fence posts, and the species is commonly harvested by local farmers. Hymenaea stigonocarpa ('jatobá-do-cerrado') displayed high values for absolute dominance and density, most likely because the tree is naturally found in soils of low chemical fertility (Carvalho, 2007), as was the case in this study, in which its abundance correlated with high soil Al contents.

The great variation in $\mathrm{P}, \mathrm{K}, \mathrm{Mn}$, and Fe contents between the plots sampled in the area of Montes Claros can be explained by the use of local soil. This is a region of intensive dairy cattle production, and the cerrado fragments are therefore surrounded by pastures belonging to different farms. Thus, the use of fire for pasture maintenance differs between owners which affects the availability of nutrients between plots. In a study conducted in the Pantanal region, Guimarães Couto et al. (2006) found significant changes in 10 of 17 study variables, associated with the occurrence of fire, with a significant increase in the mean values of $K$ and $\mathrm{Fe}$ and large immobilization of $\mathrm{P}$, as described above for Montes Claros, GO.

The eigenvalues found for the first two axes of the CCA for Ouroana were considered low in comparison with those reported by Martins et al. (2003), which indicates the existence of short gradients over which most species are distributed, and that some species vary only in relative abundance (Botrel et al., 2002).

The eigenvalues found for the first axes of the CCA for Montes Claros were relatively high in comparison with the results found by Camargos et al. (2008), Botrel et al. (2002), Martins et al. (2003) and Carvalho et al. (2005). This difference indicates that the variables analyzed here are sufficient to explain the occurrence of certain species restricted to certain specific edaphic variables. Perhaps, the location of Montes Claros de Goiás in the plains of the Claro River micro basin contributes to the increased environmental heterogeneity found in the study area, a heterogeneity confirmed by the high richness and diversity indices, which were higher than those reported for the 170 areas of 'cerrado sensu lato' compiled by Ratter et al. (2001).

\section{CONCLUSIONS}

The cerrados of Montes Claros and Ouroana are among the most diversified in the central area of the Brazilian cerrado, and the species of these cerrados are distributed according to the soil fertility levels.

Soil properties define not only the location and the abundance of species but also the cerrado phytophysiognomy.

\section{ACKNOWLEDGEMENTS}

The authors thank the Brazilian Federal Agency for the Support and Evaluation of Graduate Education (Coordenação de Aperfeiçoamento de Pessoal de Nível Superior- CAPES) for a postdoctoral scholarship awarded at the second author (Edict 001/2010 MEC/CAPES and MCT/ $\mathrm{CNPq} / \mathrm{FINEP}$ ) and the Laboratory for Systematics and Plant Ecology of the Federal Institute Goiano, Rio Verde Campus. 


\section{REFERENCES}

Arens K. As plantas lenhosas dos campos cerrados como vegetação adaptada às deficiências minerais do solo. In: Ferri MG, editor. Anais do $3^{\circ}$ Simpósio sobre o Cerrado. São Paulo: Edgard Blucher /EDUSP; 1963. p.13-115.

Botrel RT, Oliveira-Filho AT, Rodrigues LA, Curi N. Composição florística e estrutura da comunidade arbórea de um fragmento de Floresta Estacional Semidecídua em Ingaí-MG, e a influência de variáveis ambientais na distribuição das espécies. $R$ Bras Bot. 2002:25:195-213.

Bremer B, Bremer K, Chase M, Fay M, Reveal J, Soltis D, Stevens P. An update of the Angiosperm Phylogeny Group classification for the orders and families of flowering plants: APG III. Bot J Linn Soc. 2009;161:105-21.

Camargos VL, Silva AF, Meira Neto JAA, Martins SV. Influência de fatores edáficos sobre variações florísticas na Floresta Estacional Semidecídua no entorno da Lagoa Carioca, Parque Estadual do Rio Doce, MG, Brasil. Acta Bot Bras. 2008;22:75-84.

Carvalho DAC, Oliveira Filho AT, Vilela EA, Curi N, van den Berg E, Fontes MAL, Botezelli L. Distribuição de espécies arbóreo-arbustivas ao longo de um gradiente de solos e topografia em um trecho de floresta ripária do Rio São Francisco em Três Marias, MG, Brasil. R Bras Bot. 2005;28:329-45.

Carvalho PER. Jatobá do cerrado (Hymenaea stigonocarpa): Taxonomia e nomenclatura. Colombo: Embrapa Florestas; 2007. (Circular técnica, 133).

Costa FV, Oliveira KN, Nunes YRF, Menino GCO, Brandão DO, Araújo LS, Miranda WO, D'ângelo Neto S. Florística e estrutura na comunidade arbórea de duas áreas de cerrado sentido restrito no norte de Minas Gerais. Cerne. 2010;16:267-81.

Empresa Brasileira de Pesquisa Agropecuária - Embrapa. Centro Nacional de Pesquisa de Solos. Manual de métodos de análise de solo. $2^{a}$.ed. rev. atual. Rio de Janeiro: 1997. (Documentos, 1).

Felfili JM, Fagg CW. Floristic composition and structure of the "cerrado" sensu stricto on rocky soils in northern Goiás and southern Tocantins, Goiás. R Bras Bot. 2007;30:375-85.

Goodland R, Pollard R. The Brazilian cerrado vegetation: A fertility gradient. J Ecol. 1973;61:219-24.

Haridasan M. Observations on soils, foliar nutrient concentrations and floristic composition of cerrado sensu stricto and cerradão communities in central Brazil. In: Furley PA, Proctor J, Ratter JA. editors. Nature and dynamics of forest-savanna boundaries. London: Chapman \& Hall; 1992. p.171-84.

Klein RM. Southern Brazilian phytogeographic features and the probable influence of upper quaternary climatic changes in floristic distribution. B Paranaense Geoci. 1975;33:67-88.

Lopes AS, Guilherme LRG. Fertilidade do solo e produtividade agrícola. In: Novais RF, Alvarez V VH, Barros NF, Fontes RLF, Cantarutti RB, Neves JCL, editores. Fertilidade do solo. Viçosa, MG: Sociedade Brasileira de Ciência do Solo; 2007. p.1-64.

Magurran AE. Measuring biological diversity. Oxford: Blackwell Publishing; 2004.
Marimon Junior BH, Haridasan M. Comparação da vegetação arbórea e características edáficas de um cerradão e cerrado sensu stricto em áreas adjacentes sobre solo distrófico no leste de Mato Grosso, Brasil. Acta Bot Bras. 2005;19:913-26.

Martins SV, Silva NRS, Souza AL, Meira Neto JAA. Distribuição de espécies arbóreas em um gradiente topográfico de Floresta Estacional Semidecidual em Viçosa, MG. Sci For. 2003;64:172-81.

McCune B, Mefford MJ. PC-ORD. Multivariate analysis of ecological data, Version 3.0. Gleneden Beach [Oregon]: MjM Software Design; 1997.

Mueller-Dombois D, Ellenberg HA. Aims and methods of vegetation ecology. New York: JohnWiley \& Sons; 1974.

Oliveira-Filho AT, Fontes MAL. Patterns of floristic differentiation among Atlantic Forests in Southeastern Brazil and the influence of climate. Biotropica. 2000;32:793-810.

Oliveira-Filho AT, Ratter JA, Shepherd GJ. Floristic composition and community structure of a Central Brazilian gallery forest. Flora. 1990;184:103-17.

Otoni TJO, Pereira IM, Oliveira MLR, Machado ELM, Farnezi MM, Mota SLL. Componente arbóreo, estrutura fitossociológica e relações ambientais em um remanescente de cerradão em Curvelo - MG. Cerne. 2013;19:201-11.

Pereira-Silva EFL; Santos JE, Kageyama PY, Hardt E. Florística e fitossociologia dos estratos arbustivo e arbóreo de um remanescente de cerradão em uma Unidade de Conservação do Estado de São Paulo. R Bras Bot. 2004;27:533-44.

Ratter JA, Bridgewater S, Ribeiro JF. Analysis of floristic composition of Brazilian Cerrado vegetation III: Comparison of the woody vegetation of 376 areas. Edinb J Bot. 2003;60:57-109.

Ratter JA, Bridgewater S, Ribeiro JF. Espécies lenhosas da fitofisionomia cerrado sentido amplo em 170 localidades do bioma Cerrado. Bol Herb Ezechias Paulo Heringer. 2001;7:5-112.

Ribeiro JF, Silva JCS, Batmanian GJ. Fitossociologia de tipos fisionômicos de cerrado em Planaltina-DF. R Bras Bot. 1985;8:131-42.

Ribeiro JF, Walter BMT. As principais fitofisionomias do bioma cerrado. In: Sano SM, Almeida SP, Ribeiro JF, editores. Cerrado: Ecologia e flora. Brasília: Embrapa; 2008. p.151-212.

Scherer A, Maraschin-Silva F, Baptista LRM. Florística e estrutura do componente arbóreo de matas de Restinga arenosa no Parque Estadual de Itapuã, RS, Brasil. Acta Bot Bras. 2005;19:717-26.

Secretaria de Planejamento e Desenvolvimento do Estado de Goiás - Seplan-GO. Anuário estatístico do estado de Goiás. Goiânia: 2005.

Soares MP, Santos TM, Dourado DM, Silva PO, Sá JL. Análise fitossociológica do componente arbóreo de um remanescente de cerradão em Rio Verde - Goiás. Global Sci Technol. 2012;5:87-97.

Ter Braak CJE, Prentice IC. A theory of gradient analysis. Adv Ecol Res. 1988;18:271-317.

Ter Braak CJE. The analysis of vegetation-environment relationships by canonical correspondence analysis. Vegetatio. 1987;69:69-77. 